\title{
Характер наследования числа колосков в колосе у сортообразцов пшеницы мягкой яровой
}

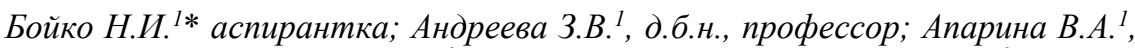
студентка; Сухомлинов В.Ю. ${ }^{2}$, агроном I категории; Пискарев В.В. ${ }^{2}$ к.с.-х.н., зав. лаб. генофонда растений.

${ }^{1}$ Новосибирский государственный аграрный университет, Новосибирск, Российская Федераиия;

${ }^{2}$ Сибирский научно-исследовательский институт растениеводства и селекици - филиал «Федерального исследовательского иентра Институт ицтологии и генетики Сибирского отделения Российской академии наук», Краснообск, Российская Федерачия.

*e-mail:n.bojko@mail.ru

В статье приведены данные о характере наследования числа колосков в колосе, выявлено, что проявление признака детерминируется 1-3 генам с проявлением доминантного и рецессивного эпистаза, а также зависит от условий, сложившихся в годы изучения. За время исследования гибридов $F_{2}$ по комбинациям Энита х Лютесиенс 77, Альбидум 31 х Баганская 51 выявлено различие по двум генам и Тулайковская золотистая х Омская 24 выявлено различие по трем генам.

Ключевые слова: пшеница, число колосков в колосе, характер наследования, эффект генов.

\section{Inheritance spikelet number per spike of spring wheat varieties}

Boyko N.I. ${ }^{1}$ postgraduate,n.bojko@mail.ru, Andreeva Z.V.' , Doctor of Biological Sciences, Professor, Aparina V.A. ${ }^{l}$, student, Sukhomlinov V.YU. ${ }^{2}$, Agronomist of I category, Piskarev V.V. ${ }^{2}$ candidate of agricultural sciences, head of the laboratory of the plant gene pool.

${ }^{I}$ Federal State Budgetary Educational Institution of Higher Education "Novosibirsk State Agrarian University", Novosibirsk Russia,

${ }^{2}$ Siberian Research Institute of Plant Production and Breeding - Branch of Federal State Budget Scientific Institution "The Federal Research Center Institute of Cytology and Genetics of Siberian Branch of the Russian Academy of Sciences".

The article presents data on inheritance spikelet number per spike. It revealed that 1-3 genes with expression of dominant and recessive epistasis determine the expression of a feature, and it depends on the conditions prevailing during the investigation. Difference in two genes was identified in combinations Enita $x$ Lutescens 77, Albidum 31 x Baganskaya 51, and three genes in Tulaykovskaya Zolotistaya $x$ Omskaya 24.

Key words: wheat, spikelet number per spike, inheritance, gene effect. 
Урожайность пшеницы представляет собой сложный признак, формирующийся из элементов структуры урожая, находящихся во взаимосвязи друг с другом. Селекционер может усилить либо ослабить один или несколько признаков для того, чтобы получить их оптимальное сочетание и, как результат, высокую продуктивность. Шелепов В.В. отдает предпочтение при увеличении урожайности числу колосков и зерен в колосе, массе 1000 зерен и зерна с одного растения [1]. Особенностью колоска пшеницы является то, что он содержит более одного зерна, что делает колосок пшеницы самым важным компонентом урожайности зерна [2]. Выявление характера наследования признака позволяет прогнозировать эффективный отбор нужных генотипов.

Цель нашего исследования - определить характер наследования числа колосков в колосе у сортообразцов пшеницы мягкой яровой.

Экспериментальную работу выполняли в 2017-2018 гг. в лесостепи Приобья в СибНИИРС - филиал ИЦиГ СО РАН. Вегетационный период 2017 г. по метеорологическим показателям характеризовался как умеренно увлажненный с повышенной теплообеспеченностью (ГТК =1,63). Метеорологические условия 2018 г. можно охарактеризовать как благоприятные для возделывания пшеницы (ГТК $=1,88)$.

Материалом для исследования служили 6 гибридных популяций, полученные в результате простых парных скрещиваний сортов пшеницы мягкой яровой с контрастной выраженностью признака. Посев проводили в оптимальные сроки, сеялкой РС-2 на глубину 5-6 см. Площадь питания растений $-200 \mathrm{~cm}^{2}$. Количество рядков от одного $\left(\mathrm{F}_{1}\right)$ до шести $\left(\mathrm{F}_{2}\right)$. Повторность 4-кратная. Предшественник - черный пар. Уход за посевами производили вручную (рыхление и прополки) по мере необходимости. Характер наследования количественных признаков определяли по формуле А. Густафссона и И. Дормлинг в процентах [3], а на ее основе определяется характер наследования по шкале, разработанной Р. А. Цильке [4]. Математическую обработку для выявления количества генов контролирующих число колосков в колосе проводили с помощью программы ПолигенА [5] по методике, описанной Костылевым П.И. (2008) [6].

Гибриды $\mathrm{F}_{1}$ в 2017 году характеризовались частичным доминированием родителя с большей выраженностью признака, за исключением комбинации Энита х Лютесценс, по которой наблюдали неполное доминирование родителя с большей выраженностью признака. При этом в 2018 году характер наследования изменялся от неполного доминирования родителя с меньшей выраженностью признака (Тулайковская золотистая х Омская 24) до частичного доминирования родителя с большей выраженностью признака (Лютесценс 77 x Энита, Энита х Лютесценс, Баганская 51 х Альбидум 31), у двух комбинаций изменений не отмечено (Лютесценс 77 x Энита и Баганская 51 x Альбидум 31). 
В целом по опыту родительские формы (табл. 1), которые формируют малое число колосков в колосе (Лютесценс 77, Альбидум 31 и Тулайковская золотистая), имели достоверно меньшее значение показателя, по сравнению с родительскими формами, формировавшими большее число колосков в колосе (Энита, Баганская 51 и Омская 24) за годы изучения. Коэффициент вариации признака по сортам Энита и Лютесценс 77 изменился от незначительной в 2017 году до средней изменчивости в 2018 году, по сорту Альбидум 31 отмечена обратная тенденция.

Таблица 1 - Статистические параметры вариации числа колосков в колосе у родительских форм (Р), Краснообск

\begin{tabular}{|c|c|c|c|c|c|c|c|}
\hline Параметры & Год & $\begin{array}{l}\tilde{\Xi} \\
\stackrel{\Xi}{\Xi}\end{array}$ & 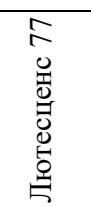 & 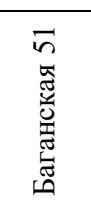 & 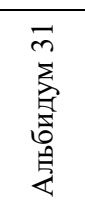 & 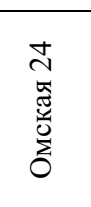 & 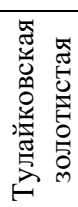 \\
\hline \multirow{2}{*}{ Среднее значение ( $\bar{X})$, шт. } & 2017 & $19,6^{*}$ & $16,2^{*}$ & $20,8^{*}$ & $15,1^{*}$ & $20,9 *$ & $15,5^{*}$ \\
\hline & 2018 & $17,5^{*}$ & $14,4^{*}$ & $18,5^{*}$ & $13,7^{*}$ & $20,1^{*}$ & $13,8^{*}$ \\
\hline \multirow{2}{*}{$\begin{array}{l}\text { Среднее квадратическое } \\
\text { отклонение (S) }\end{array}$} & 2017 & 1,6 & 1,1 & 1,6 & 1,6 & 1, & 0,2 \\
\hline & 2018 & 2,7 & 2,4 & 1,5 & 1,0 & 1,7 & 0,8 \\
\hline \multirow{2}{*}{ Ошибка выборочной ( $S_{\bar{x}}$ ) } & 2017 & 0,2 & 0,1 & 0,2 & 0,2 & 0,2 & 0,1 \\
\hline & 2018 & 0,3 & 0,4 & 0,2 & 0,1 & 0,2 & 0,1 \\
\hline \multirow{2}{*}{ Коэффициент вариации, C } & 2017 & 8,0 & 7,0 & 8,0 & 11,0 & 7,0 & 8,0 \\
\hline & 2018 & 15,0 & 16,0 & 8,0 & 8,0 & 8,0 & 6,0 \\
\hline \multirow{2}{*}{$\begin{array}{l}\text { Нижний доверительный ин- } \\
\text { тервал, шт. }\end{array}$} & 2017 & 14,6 & 12,8 & 15,9 & 10,3 & 16,5 & 12,0 \\
\hline & 2018 & 9,5 & 7,3 & 14,0 & 10,6 & 15,1 & 11,3 \\
\hline \multirow{2}{*}{$\begin{array}{l}\text { Верхний доверительный ин- } \\
\text { тервал, шт. }\end{array}$} & 2017 & 24,5 & 19,7 & 25,6 & 19,9 & 25,4 & 19,0 \\
\hline & 2018 & 25,6 & 21,5 & 23,0 & 16,9 & 25,1 & 16,2 \\
\hline
\end{tabular}

По родительским формам Лютесценс 77 и Энита выявлено различие по одному (Лютесценс 77 х Энита в 2017 г.) и двум (Лютесценс 77 х Энита в 2017 и Энита х Лютесценс 77 в 2018 г.) генам (табл. 2). Можно отметить что по комбинациям Лютесценс 77 х Энита и Энита х Лютесценс 77 в 2017 году эффект генов (d) и критерий согласия $\chi^{2}{ }_{\phi}$ были достоверны, при этом в 2018 году эффект генов (d) был достоверен, а критерий согласия $\chi_{\phi}^{2}$ не достоверен. По результатам анализа выявлен доминантный эпистаз $\mathrm{A}>\mathrm{B}=0,5$ (2017 г.) и $\mathrm{A}>\mathrm{B}=0,1$ (2018 г.) (Энита х Лютесценс 77). По комбинации Лютесценс 77 х Энита количество генов изменилось, что можно объяснить влиянием различных генов на признак в зависимости от условий выращивания. Выявлено два (Альбидум 31 х Баганская 51 в 2017 и 2018 гг. и Баганская 51 х Альбидум 31 в 2017 г.) и три (Баганская 51 х Альбидум 31 в 2018 г) гена, контролирующих число колосков в колосе, по которым различаются данные 
родительские формы. В ходе анализа был выявлен доминантный $\mathrm{B}>\mathrm{A}=0,5$ (Альбидум 31 х Баганская 51, 2017 г.) и рецессивный $\mathrm{a}>\mathrm{B}=1,0$ (Альбидум 31 x Баганская 51, 2018 г.), b>A=1,0 (Баганская 51 х Альбидум 31, 2018 г.) эпистаз. Выявлено, что родительские формы Тулайковская золотистая и Омская 24 различаются между собой по трем генам, контролирующим число колосков в колосе. По комбинации Тулайковская золотистая х Омская 24 в 2017 году был выявлен рецессивный эпистаз $\mathrm{a}>\mathrm{B}=1,0, \mathrm{a}>\mathrm{C}=1,0, \mathrm{~b}>\mathrm{A}=1,0$.

Таблица 2 - Результаты гибридологического анализа числа колосков в колосе гибридов $\mathrm{F}_{2}$ пшеницы мягкой яровой, Краснообск

\begin{tabular}{|c|c|c|c|c|}
\hline Комбинация & Год & $\begin{array}{l}\text { Критерий } \\
\text { согласия } \chi^{2} \phi\end{array}$ & $\begin{array}{l}\text { Эффект } \\
\text { генов, d }\end{array}$ & $\begin{array}{l}\text { Число генов, } \\
\text { эпистаз }\end{array}$ \\
\hline \multirow{2}{*}{ Лютесценс 77 x Энита } & 2017 & $3,54 *$ & $\mathrm{~A}=3,32 *$ & 1 \\
\hline & 2018 & 21,53 & $\mathrm{~A}$ и $\mathrm{B}=1,6^{*}$ & 2 \\
\hline \multirow{2}{*}{ Энита х Лютесценс 77} & 2017 & $2,91^{*}$ & $\mathrm{~A}$ и $\mathrm{B}=2,2^{*}$ & $2, \mathrm{~A}>\mathrm{B}=0,5$ \\
\hline & 2018 & 23,41 & А и $\mathrm{B}=1,7^{*}$ & $2, \mathrm{~A}>\mathrm{B}=0,1$ \\
\hline \multirow{2}{*}{ Альбидум 31 х Баганская 51} & 2017 & $2,93^{*}$ & $\mathrm{~A}$ и $\mathrm{B}=3,8^{*}$ & $2, \mathrm{~B}>\mathrm{A}=0,5$ \\
\hline & 2018 & 5,09 & $\mathrm{~A}$ и $\mathrm{B}=2,4^{*}$ & $2, \mathrm{a}>\mathrm{B}=1,0$ \\
\hline \multirow{2}{*}{ Баганская 51 х Альбидум 31} & 2017 & $3,22 *$ & $\mathrm{~A}$ и $\mathrm{B}=2,8^{*}$ & 2 \\
\hline & 2018 & $2,85^{*}$ & $\mathrm{~A}, \mathrm{~B}$ и $\mathrm{C}=1,6^{*}$ & $3, \mathrm{~b}>\mathrm{A}=1,0$ \\
\hline \multirow[t]{2}{*}{$\begin{array}{c}\text { Тулайковская золотистая x } \\
\text { Омская } 24\end{array}$} & 2017 & $3,18^{*}$ & $\mathrm{~A}, \mathrm{~B}$ и $\mathrm{C}=1,8^{*}$ & $\begin{array}{c}3, a>B=1,0 \\
a>C=1,0 \\
b>A=1,0\end{array}$ \\
\hline & 2018 & 20,5 & $\mathrm{~A}, \mathrm{~B}$ и $\mathrm{C}=2,1^{*}$ & 3 \\
\hline \multirow{2}{*}{$\begin{array}{c}\text { Омская } 24 \text { x Тулайковская } \\
\text { золотистая }\end{array}$} & 2017 & $4,30^{*}$ & $\mathrm{~A}$ и $\mathrm{B}=2,7^{*}$ & 2 \\
\hline & 2018 & 45,57 & $\mathrm{~A}, \mathrm{~B}$ и $\mathrm{C}=2,1^{*}$ & 3 \\
\hline \multicolumn{5}{|c|}{ Примечание: *значение достоверно при $\mathrm{P}>0,05$} \\
\hline
\end{tabular}

\section{Выводы:}

1. характер наследования числа колосков в колосе изменялся в пределах частичного и неполного доминирования родителя с большей и меньшей выраженностью признака;

2. признак «число колосков в колосе», у изученных сортов, контролируется небольшим числом генов (1-3) с проявлением доминантного и рецессивного эпистаза. За два года изучения гибридов второго поколения (20172018 гг.), количество генов, контролирующих проявление признака, по которым различаются сорта, не изменилось по комбинациям Энита х Лютесценс 77, Альбидум 31 х Баганская 51 выявлено различие по двум генам и Тулайковская золотистая х Омская 24 выявлено различие по трем генам.

\section{Список литературы}

1. Шелепов В.В. Пшеница: история, морфология, биология, селекция: монография / В.В. Шелепов [и др.]. - Мироновка: ЗАТ «Мироновская типография», 2009. - 
577 с. - 500 экз. - ISBN 966-7802-52-3.

2. Dixon L.E. TEOSINTE BRANCHED1 regulates inflorescence architecture and development in bread wheat (Triticum aestivum) / L.E. Dixon, J.R. Greenwood, S. Bencivenga, P. Zhang, J. Cockram, G. Mellers, K. Ramm, C. Cavanagh, S.M. Swain, S.A. Boden // Plant Cell - № 3 (30) - 2018. - P. 563-581. doi: 10.1105/tpc.17.00961

3. Gustafsson A. Dominance and over dominance in phytotron analysis of monohybrid barley / A. Gustafsson, I. Dormling // Hereditas - Vol. 70, № 2. - 1972. - P. 185 - 190.

4. Цильке Р.А. Изменчивость и наследование продолжительности периода всходы - колошение у эколого-отдаленных гибридов мягкой яровой пшеницы / Р.А. Цильке, И.В. Кондратьева // Актуальные задачи селекции и семеноводства сельскохозяйственных растений на современном этапе: Доклады и сообщения IX генетикоселекционной школы - Новосибирск, 2005. - С. 195-203.

5. Мережко А.Ф. Система генетического изучения исходного материала для селекции растений: (Метод. указания) / Сост. А.Ф. Мережко. - Л.: ВИР, 1984. - 70 с.

6. Костылев П.И. Генетический анализ в селекции сельскохозяйственных культур / П.И. Костылев, Л.М. Костылева. - Зерноград: ФГОУ ВПО АЧГАА, 2008. - 73 с.

DOI 10.18699/GPB2020-18

\section{Поиск и функциональный анализ генов с циркадным паттерном экспрессии у мягкой пшеницы}

Брагина М.К., м.н.с.; Киселёва А.А., к.б.н., н.с.; Салина Е.А., о.б.н., г.н.с. ИЦиГ СО РАН, Новосибирск, Россия.

e-mail: koltunova@bionet.nsc.ru

Циркадные ритмы регулируют многие аспекты физиологии растений, включая фотосинтез, цвветение, развитие и метаболизм. Поскольку циркадные часы координируют экспрессию ряда ключевых генов, контролируюших важные для сельского хозяйства признаки, основные гены, контролируюшие цииркадные ритмы являются цуентрами важных транскрипциионных сетей. Модификация этих генов может привести к системньм эффектам, которые обеспечат усиление адаптации и положительно повлияют на цельй ряд агрономических признаков. Таким образом, основной темой данной работы является изучение суточных колебаний транскриптома пшеницы, идентификация как основных циикадных генов, так и генов метаболических путей под влиянием суточных ритмов.

Ключевье слова: Triticum aеstivum, цุиркаднье ритмы, экспрессия генов.

\section{Detection and functional analysis of genes with circadian expression pattern in common wheat}

Bragina M.K., Kiseleva A.A., Salina E.A.

Institute of Cytology and Genetics SB RAS, Novosibirsk, Russia. 